\title{
THE ESSENCE AND ATTRIBUTES OF INTER-ORGANIZATIONAL RELATIONS
}

\begin{abstract}
This paper describes a valid, important and interesting scientific issue concerning the interorganizational relations, limited to the theoretical interpretation and attributes of this category. The abilities to build, develop and improve the relations between organizations are currently one of the key conditions of their effective external growth. The theory of inter-organizational relations is a response to the needs of contemporary organizations that intend to develop various forms of cooperation in order to increase the effectiveness and efficiency of the performed processes, achieve additional synergistic effects and to improve their competitive advantage.

The purpose of this paper is to present the essence and attributes of inter-organizational relations in the context of the researchers' dispute concerning the interpretation of this category. The indicated cognitive gap requires a significant epistemological effort and conceptual work. The purpose of the work has determined the research methods, including the analysis of theoretical considerations and results of the research on inter-organizational relations contained in the literature, observation of the economic practice and deductive reasoning. Due to the lack of unanimity of the researchers in defining the inter-organizational relations, the following two meanings of this concept have been proposed: sensu largo and sensu stricto. They have been introduced with reference to the presented definitions of the three concepts: relations, interactions and bonds. Assuming two perspectives in the interpretation of the described category is a new point of view in the continuing dispute of management theoreticians specialized in inter-organizational relations.
\end{abstract}

Keywords: inter-organizational relations, interactions, bonds, attributes of relationship.

\section{INTRODUCTION}

In current economic reality, inter-organizational relations (IORs) ${ }^{2}$ are characterized by high complexity and variability, which is undoubtedly related with the influence of various

\footnotetext{
${ }^{1}$ Magdalena Szydełko, PhD, Department of Management Systems and Logistics, Faculty of Management, Rzeszow University of Technology, Powstańców Warszawy Ave. 10, 35-959 Rzeszów, e-mail:mszydel@prz.edu.pl.

Dr Magdalena Szydełko, Katedra Systemów Zarządzania i Logistyki, Wydział Zarządzania, Politechnika Rzeszowska, Al. Powstańców Warszawy 10, 35-959 Rzeszów, e-mail: mszydel@prz. edu.pl.

${ }^{2}$ It must be noted that in the literature authors often refer to IORs using a variety of terms: inter-firm relationships, alliance, network, collaboration and cooperation. See: L. Agostini, A. Nosella, InterOrganizational Relationships in Marketing: A Critical Review and Research Agenda, „International Journal of Management Reviews" 2017, Vol. 19, Iss. 2, p. 133.
} 
endogenous and exogenous factors ${ }^{3}$. Unpredictable environment, particularly difficult development conditions as well as the rate of changes in economy force enterprises to set proper directions of growth. They may either "try to operate individually, or decide to pursue various forms of inter-organizational cooperation" 4 . Some enterprises, especially small- and mediumsized enterprises, have some significant limits related to their dimension that restricts their ability to internationalize, innovate and cope with competitive and environmental pressures. In order to overcome these shortcomings, enterprises often complement their scarce resource base by engaging in different kinds of inter-organizational relationships ${ }^{5}$.

Currently, management sciences promote the paradigms of relations and cooperation of enterprises. According to E.I. Stańczyk-Hugiet, "many authors accept the relations paradigm, but it is still at the stage of formulation, while the research in inter-organizational relations has been continued in the recent period due to the fact that the number of organizations that shaped their strategic growth path by building relations was increasing"6 . C. Rossignoli and F. Ricciardi emphasizes that "inter-organizational relationships are driving growing attention among management scholars: this is a viable and fascinating field of studies, because it is more and more evident that organizations do not succeed or fail in isolation, but as parts of wider networks and social ecosystems"7.

Development of inter-organizational relations, including cooperation of entities, is currently one of the key challenges of strategic management. W. Czakon claims that it is related with three megatrends in the contemporary economy ${ }^{8}$ :

1) deconstruction of the value chain, that implies the need to cooperate to specialize and implement the economies of scale,

2) hyper-competition, leading to the "erosion" of competitive advantage that forces companies to become flexible,

3) networking, consisted in creation of groups of cooperating units.

Definitions and terminology are often subjects of scientific discussions and disputes, at least in the field of social sciences. Thus, presenting the essence and attributes of inter-organizational relations should be supported with more detailed information on the researchers' considerations concerning the definitions of the three concepts of: relations, interactions and interorganizational bonds. The review and analysis of the definitions of these categories leads to the fact that the literature does not provide any exact solution to distinguish them. The researchers treat them either as synonymous categories, using them alternatively, even in different contexts, or conversely, as opposite terms. The variety of definitions of these categories is the result of the

${ }^{3}$ M. Szydełko, Atrybuty i czynniki sukcesu partnerstwa przedsiębiorstw, "Modern Management Review" 2014, Vol. XIX, No. 4, p. 231.

${ }^{4}$ J. Niemczyk, B. Jasiński, Wstęp [in:] Sieci międzyorganizacyjne. Wspótczesne wyzwanie dla teorii i praktyki zarzadzania, ed. J. Niemczyk, E. Stańczyk-Hugiet, B. Jasiński, C.H. Beck, Warszawa 2012, p. 10.

5 J. Partanen, S.K. Chetty, A. Rajala, Innovation types and network relationships, „Entrepreneurship Theory and Practice" 2014, Vol. 38, Iss. 5.

${ }^{6}$ E.I. Stańczyk-Hugiet, Dynamika strategiczna w ujęciu ewolucyjnym, Wydawnictwo Uniwersytetu Ekonomicznego we Wrocławiu, Wrocław 2013, p. 52.

7 C. Rossignoli, F. Ricciardi, Inter-Organizational Relationships. Towards a Dynamic Model for Understanding Business Network Performance, Springer International Publishing, Switzerland 2015, p. 1.

8 W. Czakon, Koordynacja sieci - wieloraka forma organizacji wspótdziatania, „Przegląd Organizacji” 2008, No. 9, p. 7-10. 
shift of emphasis to other elements used to describe them. In the aspect of effectiveness and suitability of scientific research in the field of relations, the linguistic process consisted in using the concepts of relations, interactions and bonds alternatively, seems improper. In this connection, an attempt to justify this opinion has been made by presenting selected interpretations of the listed conceptual categories.

\section{OBJECTIVE AND METHODOLOGY OF CONCEPTUAL RESEARCH}

In this paper, the Author intends to present the theoretical and conceptual results of the research focused on the interpretation of the concept of inter-organizational relations in two aspects: narrow and broad, and also on the identification of key factors allowing to explain their specificity.

The goal of the study is a synthetic presentation of the essence and the attributes of interorganizational relations in view of various theoretical interpretations and also the properties of this category presented in the literature. This study has been prepared with the use of the following research methods: the analysis of theoretical considerations and results of the research on inter-organizational relations contained in the literature sources, observation of the economic practice and deductive reasoning. The selection of the specific field of theoretical considerations and conceptual works has been motivated by the dispute of the researchers in defining interorganizational relations and the lack of unanimous distinction of their major features.

This paper describes a valid, important and interesting scientific issue concerning the interorganizational relations. The author believes that the results of this analysis may become a new point of view in the continuing dispute of the management theoreticians specialized in interorganizational relations management.

\section{CORE CONCEPTS IN THE STUDY OF IINTER-ORGANIZATIONAL RELATIONS}

In the encyclopaedic aspect, relations are defined as "any connection, correlation, relationship, etc. between elements, objects or processes" 9 . The sensu stricto approach to the essence of relations has been proposed by T. Pszczołowski, who suggested explaining it through exemplification, assuming the epistemological originality of the concept of relation ${ }^{10}$. In his opinion, relation is a "relationship, (...) any dependence, connection between entities of any type, e.g. due to their similarity, causal link, mutual influence (bond), size correlation (one entity is larger than the other, smaller one), spatial correlation (closer, further), time correlation (earlier, simultaneous, later)" ${ }^{11}$.

In management sciences, relations are the subject of the research at the following levels:

1) intra-organizational (e.g. interpersonal relations, relations between organizational units),

2) inter-organizational (e.g. relations between competitors, relations in distribution channels).

9 Encyklopedia organizacji i zarządzania, Państwowe Wydawnictwo Ekonomiczne, Warszawa 1981, p. 441.

10 T. Pszczołowski, Mała encyklopedia prakseologii i teorii organizacji, Zakład Narodowy im. Ossolińskich, Wrocław 1978, p. 206.

11 Ibidem. 
A. Sudolska claims that relations in reference to enterprises determine the scope and degree of connections between them, while the concept of relations concerns the way in which they behave towards each other ${ }^{12}$. The literature also provides a comparison of relations and a "chest" that contains various "items", e.g. common experiences of relation parties or trained rules and standards of behaviour ${ }^{13}$.

It must be emphasized that relations between enterprises should not be analyzed in a dichotomous approach $^{14}$. The focus of some researchers on answering the question whether relations may be created in given circumstances, is not sufficient to satisfy the actual requirements of the theory and practice of management. In this connection, the research should encompass relations in a qualitative approach, which means focusing on the essence and the quality of relations between enterprises, the conditions of changes within these relations as well as the factors that stimulate and destimulate the creation of various types of relations.

While considering the essence of relations, the difference between this concept and interactions must be noted. According to T. Pszczołowski, interaction is "the impact of one party on another party, with a mainly informative character" 15 . Interactions, commonly referred to as contacts, can be divided into:

1) microinteractions (personal contacts),

2) macrointeractions (e.g. contacts of an organization with the environment).

The literature distinguishes the following features of interactions:

1) frequency,

2) duration,

3) direction (who interacts with whom),

4) range (who interacts, how often and with whom),

5) location (place and time),

6) content of the information provided in the course of the interaction,

7) method of interaction (verbal or non-verbal),

8) emotional emphasis.

The relations and interactions on the market of industrial goods have been studied by J. Johanson and L.G. Mattsson. In their analyses of the essence of these conceptual categories, they pointed out several critical aspects. The factors favourable for development of permanent relations between enterprises included: focus on reciprocity, outlays (common investments), bonds and mutual dependence. Interactions are supported by mutually related processes of exchange and adaptation ${ }^{16}$. A similar view has been presented by M. Kowalska-Musiał, who claimed that "the processes of interactions are specific for entities operating in the field of exchange" 17.

12 A. Sudolska, Uwarunkowania budowania relacji proinnowacyjnych przez przedsiębiorstwa w Polsce, Wydawnictwo Naukowe Uniwersytetu Mikołaja Kopernika, Toruń 2011, p. 27.

13 Ibidem.

${ }^{14}$ P. Turnbull, D. Ford, M. Cunningham, Interaction, Relationships and Networks in Business Markets: an Evolving Perspective, "Journal of Business \& Industrial Marketing" 1996, Vol. 11, No. $3 / 4$, p. 45.

15 T. Pszczołowski, Mała encyklopedia..., p. 88.

${ }^{16}$ J. Johanson, L.G. Mattsson, Interorganizational Relations in Industrial Systems: A Network Approach Compared with the Transaction-Cost Approach, "International Studies of Management \& Organization" 1987, Vol. 17, No. 1, p. 37-40.

${ }_{17}$ M. Kowalska-Musiał, Metodologiczne ujęcie morfologii relacji w nowej gospodarce, congress materials, IX Kongres Ekonomistów Polskich, Polskie Towarzystwo Ekonomiczne, Warszawa 2013, http://www.pte.pl/kongres/referaty/index.php (available: 28 March 2018). 
J. Johanson and L.G. Mattsson distinguished the differences between relations and interactions on the industrial goods market. The graphical representation of key factors that differentiate both concepts is presented in Figure 1.

An inter-organizational relation is a mutual (reciprocal) orientation of two parties ${ }^{18}$. It means that they are ready to establish contacts (interactions) and expect the same from the other party. The focus on reciprocity also means that representatives of the parties have knowledge of each other, are aware of the mutual interest and are ready to give their attention to the other party of the relation. Additionally, the parties that form relations:

1) invest in such relations,

2) create formal and informal bonds,

3) are mutually dependent.

\begin{tabular}{ll|}
\hline \multicolumn{1}{|c|}{ RELATIONSHIPS } & INTERACTION \\
\cline { 2 - 2 } Mutual orientation & Exchange processes \\
- preparedness to interact & - social exchange \\
- mutual knowledge & - business exchange \\
- respect for each other's interests & - information exchange \\
Investments & Adaptation processes \\
Bonds & - products \\
Dependence & - production \\
& - routines
\end{tabular}

Figure 1. Relationships and interaction in industrial markets

Source: J. Johanson, L.G. Mattsson, Interorganizational Relations in Industrial Systems: A Network Approach Compared with the Transaction-Cost Approach, ,International Studies of Management \& Organization” 1987, Vol. 17, No. 1, p. 38.

In the literature, the most common opinion says that inter-organizational relations emerge and develop through interactions. J. Johanson and L.G. Mattsson claim that interactions are elements of the processes of ${ }^{19}$ :

1) exchanging the possessed resources by the relation parties,

2) adaptation, i.e. mutual adjustment of relation parties to the changing conditions of cooperation and expectations, e.g. in terms of modification of the production process or procedures.

It must be pointed out that continuous processes of exchange and adaptation are the evidence of the dynamics of relations in the economic practice.

For the purposes of this paper, the following theoretical interpretation of the concept of interaction has been accepted: it is a process of mutual "stimulus-response" reaction, performed through a direct contact between the parties operating in the field of exchange of assets and adjusting to the expectations of the other party, according to commonly agreed conditions.

\footnotetext{
18 J. Johanson, L.G. Mattsson, Interorganizational..., p. 37.

19 Ibidem, pp. 37-40.
} 
Another concept present in the literature refers to inter-organizational bonds. It is the third conceptual category that should be interpreted. According to the encyclopaedic definition, a bond is a "relation of common dependences (...) between the parts of the organization, including the members of the organization (organizational bond), expressed as input or informative interactions (reaction)" ${ }^{20}$. It should be underlined that this definition is incomplete due to the lack of the inter-organizational context. Inter-organizational bonds, as a subject of research in the field of relations, are "specific reactions between two or more enterprises, where the emphasis is put to those reactions, not the parties of the relation"21. It must be emphasised that these are "reactions in which informative, material or energetic exchange occurs, while the parties of the exchange manifest involvement, and that attitude is mutual"22.

It is worth noting that all bonds are relations, but not all relations are bonds. One of the examples may be a horizontal relation between competing entities, without the features of bonds, such as: exchange (material, informative, energetic), involvement (outlays) and reciprocity (symmetry of involvement and exchange). In this connection, using the concepts of relations and inter-organizational bonds alternatively is accepted only in certain situations.

The ambiguity of the concept of inter-organizational relations has already been noticed by S. Cropper and M. Ebers, who presented a set of terms connected with relations, most common in the practice and theory of management. Their study concerned the three following aspects: names of inter-organizational entities, description of inter-organizational entities and names of inter-organizational acts. The terminology of inter-organizational relations according to the authors mentioned above is presented in Table 1.

Table 1. Commonly used IOR language

\begin{tabular}{|c|c|c|c|}
\hline \multicolumn{4}{|c|}{ Names for inter-organizational entities } \\
\hline $\begin{array}{l}\text { an alliance } \\
\text { a collaboration } \\
\text { a federation } \\
\text { a partnership }\end{array}$ & $\begin{array}{l}\text { an association } \\
\text { a consortium } \\
\text { a joint venture } \\
\text { a relationship }\end{array}$ & \begin{tabular}{|l|} 
a cluster \\
a constellation \\
a network \\
a strategic alliance \\
\end{tabular} & $\begin{array}{l}\text { a coalition } \\
\text { a cooperation } \\
\text { a one stop shop } \\
\text { a zone }\end{array}$ \\
\hline \multicolumn{4}{|c|}{ Description for inter-organizational entities } \\
\hline $\begin{array}{l}\text { collaborative ... } \\
\text { inter-organizational ... } \\
\text { multi-agency ... } \\
\text { trans-organizational } \\
\ldots\end{array}$ & $\begin{array}{l}\text { cooperative ... } \\
\text { inter-professional ... } \\
\text { multi-party ... } \\
\text { virtual ... }\end{array}$ & $\begin{array}{l}\text { coordinated ... } \\
\text { joined-up ... } \\
\text { multi-organizational... }\end{array}$ & $\begin{array}{l}\text { interlocking ... } \\
\text { joint ... } \\
\text { multiplex ... }\end{array}$ \\
\hline \multicolumn{4}{|c|}{ Names for inter-organizational acts } \\
\hline $\begin{array}{l}\text { bridging } \\
\text { franchising } \\
\text { working together }\end{array}$ & $\begin{array}{l}\text { collaboration } \\
\text { networking }\end{array}$ & $\begin{array}{l}\text { contracting } \\
\text { outsourcing }\end{array}$ & $\begin{array}{l}\text { cooperation } \\
\text { partnering }\end{array}$ \\
\hline
\end{tabular}

Source: S. Cropper et al., Introducing Inter-organizational Relations [in:] The Oxford Handbook of Interorganizational Relations, ed. S. Cropper et al., Oxford University Press, Oxford 2008, p. 5.

20 T. Pszczołowski, Mała encyklopedia..., p. 270.

${ }^{21}$ W. Czakon, Dynamika więzi międzyorganizacyjnych przedsiębiorstwa, Wydawnictwo Akademii Ekonomicznej w Katowicach, Katowice 2007, p. 38.

22 Ibidem, p. 44. 
It is important to note that the definitions and considerations of the researches cited previously, present the ambiguity of concepts, specific for management sciences. For the purposes of this paper, the following two meanings of inter-organizational relations have been proposed: sensu largo and sensu stricto. This interpretation of the concept of relations has been motivated by the differentiation of two basic types of relations, proposed by L. Krzyżanowski. These are $^{23}$ :

1) relationships as an epistemological category,

2) reactions as an ontological category.

In sensu largo approach, inter-organizational relations are relationships or any dependencies between organizations, recognized in a cognitive sense, distinguished due to an accepted criterion, e.g.:

1) degree of competition between market entities in concluding transactions (e.g. competing, coexistence),

2) size dependence (e.g. one market entity is larger than the other, entities belong to the group of medium enterprises),

3) impact degree (e.g. cooperation),

4) type of dependence (superiority, subsidiarity),

5) direction of dependence (e.g. one-way dependence, mutual dependence).

In sensu stricto approach, inter-organizational relations are the actual interactions between the entities, in which information, material or energetic exchange takes place, with the assumption of common goals and symmetry of involvement of the participants of the exchange and adaptation processes. An example of such inter-organizational relation is cooperation of enterprises.

To make these definitions more exact, is should be added that relation parties are not only enterprises. Public sector organization, state agencies, local governments and entities appointed by them and also non-governmental organizations may participate as well.

Finally, in the context of the presented definition of inter-organizational relations in sensu stricto approach, it must be mentioned that they are shaped by three essential elements:

1) relation parties,

2) assets of relations parties,

3) processes (chains of sequential actions) performed by the involved parties.

\section{KEY ATTRIBUTES OF INTER-ORGANIZATIONAL RELATIONS}

The analysis of the essence of inter-organizational relations should be performed taking into account the fact that literature sources indicate several features that allow to explain the uniqueness of such relations. Epistemological pluralism has led to the formulation of many attributes of inter-organizational relations by many researchers.

Table 2 presents a set of attributes of inter-organizational relations mentioned in the literature. Fields marked with " + " indicate that the researcher identified a given attribute.

\footnotetext{
${ }^{23}$ L. Krzyżanowski, O podstawach kierowania organizacjami inaczej: paradygmaty, modele, meta-
} fory, filozofia, metodologia, dylematy, trendy, PWN, Warszawa 1999, p. 165. 
Table 2. Attributes of inter-organizational relations according to selected authors

\begin{tabular}{|c|c|c|c|c|c|c|c|c|c|c|}
\hline Author & 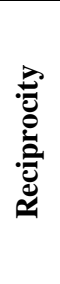 & $\frac{\hat{E}^{n}}{\bar{\Xi}}$ & 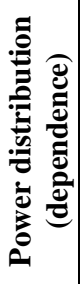 & 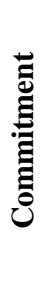 & 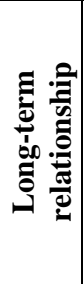 & 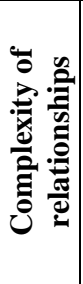 & 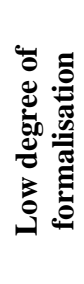 & 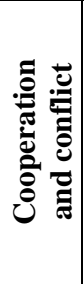 & 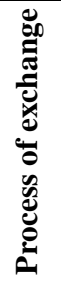 & 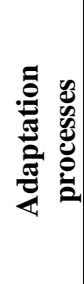 \\
\hline J. Johanson, L.G. Mattsson ${ }^{24}$ & + & + & + & & & & & & + & + \\
\hline S.M. Schmidt, T.A. Kochan 25 & + & & + & & & & & & + & \\
\hline H. Håkansson, I. Snehota ${ }^{26}$ & + & & & & + & + & + & + & & + \\
\hline L. Krzyżanowski ${ }^{27}$ & & & & + & & & & & + & + \\
\hline C. Baccarani $^{28}$ & + & & & + & + & & & & + & \\
\hline W. Ulaga, A. Eggert ${ }^{29}$ & + & & & + & & & & & + & \\
\hline W. Czakon ${ }^{30}$ & + & + & & + & & & & & + & \\
\hline S. Cropper i in. ${ }^{31}$ & + & & & & + & & & & & \\
\hline F. Kay ${ }^{32}$ & + & & + & + & + & & & & & \\
\hline K. Rupik ${ }^{33}$ & + & & & & & & & & & \\
\hline A. Sudolska ${ }^{34}$ & + & + & & + & + & & & & & + \\
\hline M. Kowalska-Musiał ${ }^{35}$ & + & & + & & + & & & & + & \\
\hline
\end{tabular}

Source: individual study based on source materials.

The essential features attributed to relations include:

1) reciprocity that usually means mutual involvement and exchange,

2) outlays on fulfilment of common goals,

${ }^{24}$ J. Johanson, L.G. Mattsson, Interorganizational..., p. 34-48.

${ }^{25}$ S.M. Schmidt, T.A. Kochan, Interorganizational Relationships: Patterns and Motivations, “Administrative Science Quarterly" 1977, Vol. 22, p. 220-234.

${ }^{26}$ H. Håkansson, I. Snehota, Developing Relationships in Business Networks, Routledge, London 1995, p. 7-9.

${ }^{27}$ L. Krzyżanowski, O podstawach kierowania..., p. 165-170.

${ }^{28}$ C. Baccarani, Le relazioni tra impresa e mercato: una questione di potere e di rispetto, "Sinergie" 2005, p. 149-157.

${ }^{29}$ W. Ulaga, A. Eggert, Relationship value and relationship quality. Broadening the nomological network of business-to-business relationships, "European Journal of Marketing" 2006, Vol. 40, No. 3/4, p. 311-327.

30 W. Czakon, Dynamika więzi..., p. 35-49.

${ }^{31}$ S. Cropper i in., Introducing..., p. 3-17.

${ }^{32}$ F. Kay, How to Build Successful Business Relationships, The Institution of Engineering and Technology, London 2009, p. 154-158.

${ }^{33}$ K. Rupik, Istota i zakres relacji [in:] Relacje podmiotów rynkowych $w$ warunkach zmian, ed. K. Bilińska-Reformat, Placet, Warszawa 2009, p. 60-70.

34 A. Sudolska, Uwarunkowania budowania..., p. 23-32.

${ }^{35}$ M. Kowalska-Musiał, Metodologiczne ujęcie... 
3) distribution of power that means the capability of one party of the relation to influence the behaviour of the other party,

4) involvement consisted in active contribution to the process of deepening and improvement of the existing relations,

5) long-term relationship,

6) information, material or energy exchange,

7) adaptation consisted in adjustment to the expectations of the other party of the relation and to the changing conditions of business environment.

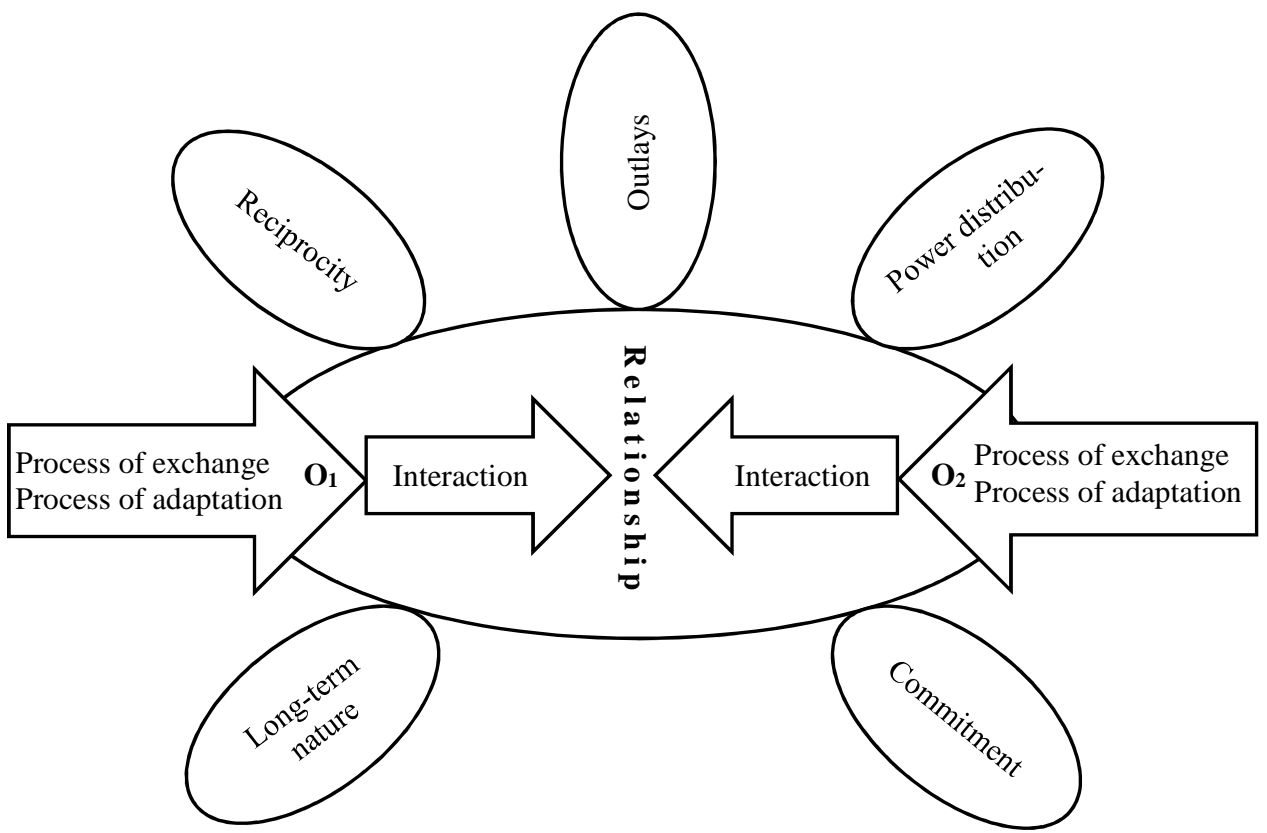

Figure 2. Graphical representation of the essence and attributes of inter-organizational relations

Source: Author's own work.

It is worth noticing that H. Håkansson and I. Snehota have identified three additional features of relations that are rarely mentioned in the literature. These are ${ }^{36}$ :

1) complexity of relations between the parties of the relation, in terms of the number, forms and goals of contacts,

2) low degree of formalization of relations, that is perceived as a stimulant for establishing and maintaining relations, in particular in the circumstances of unexpected conflicts and uncertainty,

3) simultaneous cooperation and conflicts between the parties of the relation, which is an unavoidable phenomenon in long-term collaboration of entities striving for fulfilment of specific goals.

\footnotetext{
${ }^{36}$ H. Håkansson, I. Snehota, Developing Relationships...
} 
The presented interpretation of the concept of inter-organizational relations in sensu stricto approach, as well as the analysis of their attributes most often referred to in the literature, constitute an input to the graphical representation of the relations between organizations $\mathrm{O}_{1}$ and $\mathrm{O}_{2}$. Figure 2 presents the essence of the relation, indicating the direction of impact of the exchange and adaptation processes on the interactions between the parties of the relation, as well as the key factors of the relation.

Finally, in the context of the presented approaches in defining the concept of relations, it must be pointed out that the mentioned attributes concern both bilateral and multilateral systems. The following ascertainment of A. Sudolska is also worth mentioning: "strengthening the capability of enterprise to compete effectively on the market is fostered by the bonds with entities functioning in their chains of values, but also, or above all, with partners having complementary assets" 37 .

\section{CONCLUSIONS}

The purpose of the conceptual considerations was to indicate the essence and attributes of inter-organizational relations. This study lead to a conclusion that both in literature and in economic practice, the concept of relations is interpreted in various ways, which results in the ambiguity of its definition. The definition of the essence of inter-organizational relations proposed by the author has been determined by two key approaches. Assuming two perspectives in interpreting the analyzed category (sensu largo and sensu stricto approach) is a new point of view in the continuing dispute of management theoreticians specialized in inter-organizational relations management. Determining the essence and identifying the key attributes of inter-organizational relations are important in the aspect of further research. The major conclusions of the conducted analysis may be considered both epistemological and practical implications. These issues are important in the practical perspective, since the number of organizations that shape their strategic growth path by building and developing relations with other entities, is increasing.

Inter-organizational relations often form very complex systems of cooperation. Their distinctive features, also referred to as the attributes or peculiarities, include above all: focus on reciprocity, outlays on fulfilment of common goals, capability to influence behaviour of the other party of the relation, involvement, long-term connections as well as processes of exchange and adaptation.

Relations may occur between market competitors, but they may also be built by non-competing organizations. Additionally, they may be shaped within various organizational forms, e.g. industrial associations or clusters.

Undoubtedly, the popularity of relations between organizations determines the conditions of building competitive advantage and raises sectoral entrance barriers. In case of broad scope and high effectiveness of relations in systems of cooperation with the environment, organizations strengthen their competitive advantage, which is evidenced by the results of empirical analyses presented in the subject literature, as well as the outcomes of observation of inter-organizational relations development.

\footnotetext{
37 A. Sudolska, Partnerstwo przedsiębiorstw jako czynnik rozwoju ich kompetencji strategicznych [in:] Zarzadzanie strategiczne w praktyce i teorii, ed. A. Kaleta, K. Moszkowicz, „Prace Naukowe Uniwersytetu Ekonomicznego we Wrocławiu” 2010, No. 116, p. 418.
} 


\section{REFERENCES}

1. Agostini L., Nosella A., Inter-Organizational Relationships in Marketing: A Critical Review and Research Agenda, „International Journal of Management Reviews” 2017, Vol. 19, Iss. 2.

2. Baccarani C., Le relazioni tra impresa e mercato: una questione di potere e di rispetto, "Sinergie" 2005.

3. Cropper S. et al., Introducing Interorganizational Relations [in:] The Oxford Handbook of Interorganizational Relations, ed. S. Cropper et al., Oxford University Press, Oxford 2008.

4. Czakon W., Koordynacja sieci - wieloraka forma organizacji wspótdziałania, „Przegląd Organizacji” 2008, No. 9.

5. Czakon W., Dynamika więzi międzyorganizacyjnych przedsiębiorstwa, Wydawnictwo Akademii Ekonomicznej w Katowicach, Katowice 2007.

6. Encyklopedia organizacji i zarzadzania, Państwowe Wydawnictwo Ekonomiczne, Warszawa 1981.

7. Håkansson H., Snehota I., Developing Relationships in Business Networks, Routledge, London 1995.

8. Johanson J., Mattsson L.G., Interorganizational Relations in Industrial Systems: A Network Approach Compared with the Transaction-Cost Approach, "International Studies of Management \& Organization" 1987, Vol. 17, No. 1.

9. Kay F., How to Build Successful Business Relationships, The Institution of Engineering and Technology, London 2009.

10. Krzyżanowski L., O podstawach kierowania organizacjami inaczej: paradygmaty, modele, metafory, filozofia, metodologia, dylematy, trendy, PWN, Warszawa 1999.

11. Niemczyk J., Jasiński B., Wstęp [in:] Sieci międzyorganizacyjne. Wspótczesne wyzwanie dla teorii i praktyki zarządzania, ed. J. Niemczyk, E. Stańczyk-Hugiet, B. Jasiński, C.H. Beck, Warszawa 2012.

12. Partanen J., Chetty S.K., Rajala A., Innovation types and network relationships, „Entrepreneurship Theory and Practice" 2014, Vol. 38, Iss. 5.

13. Pszczołowski T., Mała encyklopedia prakseologii i teorii organizacji, Zakład Narodowy im. Ossolińskich, Wrocław 1978.

14. Rossignoli C., Ricciardi F., Inter-Organizational Relationships. Towards a Dynamic Model for Understanding Business Network Performance, Springer International Publishing, Switzerland 2015.

15. Rupik K., Istota i zakres relacji [in:] Relacje podmiotów rynkowych $w$ warunkach zmian, ed. K. Bilińska-Reformat, Placet, Warszawa 2009.

16. Schmidt S.M., Kochan T.A., Interorganizational Relationships: Patterns and Motivations, "Administrative Science Quarterly" 1977, Vol. 22.

17. Stańczyk-Hugiet E.I., Dynamika strategiczna w ujęciu ewolucyjnym, Wydawnictwo Uniwersytetu Ekonomicznego we Wrocławiu, Wrocław 2013.

18. Sudolska A., Partnerstwo przedsiębiorstw jako czynnik rozwoju ich kompetencji strategicznych [in:] Zarzadzanie strategiczne $w$ praktyce $i$ teorii, ed. A. Kaleta, K. Moszkowicz, „Prace Naukowe Uniwersytetu Ekonomicznego we Wrocławiu” 2010, No. 116.

19. Sudolska A., Uwarunkowania budowania relacji proinnowacyjnych przez przedsiębiorstwa w Polsce, Wydawnictwo Naukowe Uniwersytetu Mikołaja Kopernika, Torun 2011. 
20. Szydełko M., Atrybuty i czynniki sukcesu partnerstwa przedsiębiorstw, „Modern Management Review” 2014, Vol. XIX, No. 4.

\section{INTERNET SOURCES}

1. Kowalska-Musiał M., Metodologiczne ujęcie morfologii relacji w nowej gospodarce, Materiały kongresowe, IX Kongres Ekonomistów Polskich, Polskie Towarzystwo Ekonomiczne, Warszawa 2013, http://www.pte.pl/kongres/referaty/index.php (available: 28.03.2018).

\section{ISTOTA I ATRYBUTY RELACJI MIĘDZYORGANIZACYJNYCH}

Autorka podejmuje w artykule aktualny, ważny i interesujący poznawczo problem badawczy dotyczący relacji międzyorganizacyjnych zawężony do interpretacji teoretycznej i atrybutów tej kategorii. Umiejętności budowania, rozwoju i doskonalenia relacji między organizacjami są obecnie jednym z kluczowych warunków ich skutecznego wzrostu zewnętrznego. Teoria relacji międzyorganizacyjnych jest odpowiedzią na potrzeby współczesnych organizacji, które chcą pójść w kierunku różnego rodzaju form współpracy w celu np. zwiększania efektywności i skuteczności realizowanych procesów oraz uzyskania dodatkowych efektów synergicznych i przewagi konkurencyjnej.

Celem artykułu jest wskazanie istoty i atrybutów relacji międzyorganizacyjnych w świetle polemiki badaczy dotyczącej postrzegania tej kategorii. Wskazana luka poznawcza w obszarze relacji między organizacjami wymaga istotnego wysiłku teoriotwórczego i pracy koncepcyjnej. Postawiony cel zdeterminował wybór takich metod badawczych, jak: analiza teoretycznych rozważań i wyników badań relacji międzyorganizacyjnych zawartych w literaturze, obserwacja praktyki gospodarczej oraz rozumowanie dedukcyjne.

Ze względu na brak jednomyślności badaczy w zakresie definiowania relacji międzyorganizacyjnych zaproponowano dwa znaczenia tego pojęcia: sensu largo i sensu stricto. Dokonano tego w świetle zaprezentowanych ujęć definicyjnych triady pojęć: relacje, interakcje i więzi międzyorganizacyjne. Przyjęcie dwóch perspektyw w interpretowaniu przedmiotowej kategorii stanowi nowy głos w toczącej się polemice teoretyków zarządzania specjalizujących się w zarządzaniu relacjami międzyorganizacyjnymi. Rozstrzygnięcie istoty i identyfikacja kluczowych atrybutów relacji międzyorganizacyjnych są ważne z punktu widzenia dalszych badań. Kwestie te są również ważne z perspektywy praktycznej, ponieważ coraz więcej organizacji kształtuje swoją strategiczną ścieżkę rozwoju poprzez budowanie i rozwijanie relacji $\mathrm{z}$ innymi podmiotami.

Słowa kluczowe: relacje międzyorganizacyjne, interakcje, więzi, atrybuty relacji.

DOI: $10.7862 /$ rz.2018.hss.89

Tekst złożono do redakcji: kwiecień 2018 r.

Tekst przyjęto do druku: grudzień 2018 r. 